\title{
三島睦夫 学位論文審査要旨
}

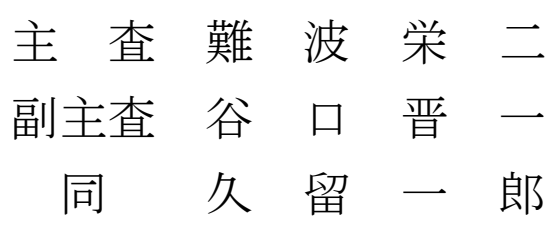

\section{主論文}

Effects of uric acid on the NO production of HUVECs and its restoration by urate lowering agents

（尿酸のヒト臍帯静脈内皮細胞のNO産生に及ぼす影響と尿酸降下薬による回復）

（著者：三島睦夫、演田紀宏、Maharani Nani、池田信人、大野原岳史、野津智美、

二宮治明、宮崎聡、水田栄之助、杉原志伸、加藤雅彦、荻野和秀、桑原政成、

廣田裕、吉田明雄、大谷直由、安西尚彦、久留一郎)

平成28年 Drug Research 66巻 270頁～274頁

\section{参考論文}

1. A vasodilating $\beta_{1}$ blocker celiprolol inhibits muscular release of uric acid precursor in patients with essential hypertension

(血管拡張性 $\beta$ 遮断薬セリプロロールは本態性高血圧患者の骨格筇由来尿酸前駆物質 の放出を抑制する）

(著者：水田栄之助、Sulistiyati Bayu Utami、太田原顕、遠藤哲、三島睦夫、

長谷川輝、山田健作、加藤雅彦、山本一博、荻野和秀、二宮治明、宮崎聡、

演田紀宏、谷口晋一、程継東、久留一郎）

平成25年 Hormone and Metabolic Research 45巻 69頁～73頁 
2. Effects of cilnidipine on serum uric acid level and urinary nitrogen monoxide excretion in patients with hypertension

（高血圧患者における血清尿酸值と尿中一酸化窒素排泄に関するシルニジピンの作用） （著者：演田紀宏、山田健作、水田栄之助、渡邊ありさ、尾崎知博、石田勝則、 長谷川輝、坂田晋史、三島睦夫、荻野和秀、野坂美仁、宮崎聡、太田原顕、 二宮治明、加藤雅彦、吉田明雄、谷口晋一、山本一博、久留一郎）

平成24年 Clinical and Experimental Hypertension 34巻 470頁〜473頁

3. Protective effects of topiroxostat on an ischemia-reperfusion model of rat hearts

(ラット心臓の虚血再灌流モデルに対するトピロキソスタットの保護効果)

（著者：丹野翔伍、山本堅志郎、倉田康孝、足立真彩、井上裕美子、大谷直由、 三島睦夫、山本康孝、桑原政成、荻野和秀、三明淳一朗、二宮治明、白吉安昭、 岡田太、山本一博、久留一郎)

平成30年 Circulation Journal 82巻 1101頁～1111頁 


\section{学 位 論 文 要 旨}

Effects of uric acid on the NO production of HUVECs and its restoration by urate lowering agents

（尿酸のヒト臍帯静脈内皮細胞のNO産生に及ぼす影響と尿酸降下薬による回復）

高尿酸血症は血管内皮機能障害の危険因子と成り得る。その機序と して尿酸が血管内皮細胞のNO産生を減少させることが推定されている が、その詳細は不明である。最近、可溶性尿酸が尿酸輸送体（UATs）を 介して細胞内に蓄積し血管炎症を惹起し、尿酸輸送体の阻害薬であるプ ロベネシドが、これを減弱し得るとの報告がある。本研究では、ヒ卜臍 帯静脈内皮細胞（HUVECs）を用い、尿酸がUATsの活性化を介して細胞内でN0 産生を障害するという仮定を立てて、UATs阻害薬であるべンズブロマロン、 ロサルタン、イルベサルタンの存在と非存在下での尿酸によるHUVECsのNO 産生と内皮型NO合成酵素（eNOS）タンパク質の発現に及ぼす影響について分 子生物学的、生化学分析を用いて検証した。

\section{方 法}

培養HUVECsを用いてRNAを抽出し、UATsのmRNA発現をRT-PCRを用いて検討し た。ベンズブロマロン、ロサルタン、イルベサルタンの存在下並びに非存在 下でHUVECsを 24 時間尿酸 $7 \mathrm{mg} / \mathrm{d} 1$ に暴露した後に、培養液中での NO産生と HUVECsの eNOS蛋白発現を検討した。NO産生はNO特異的色素を用いて、その 蛍光をマイクロプレート蛍光リーダーにより測定した。HUVECsのeNOSおよび リン酸化eNOSの蛋白発現はそれぞれの特異的抗体を用いてウエスタンブロッ ティングにより検出し、その信号をNIH image J Softwareを用いて定量化し た。統計解析は、分散分析 (ANOVA) と5\%有意水準でのチューキー法を用いて 多群間で比較した。

\section{結 果}

HUVECsにはURATv1、ABCG2、MRP4、MCT9という4種類のUATsmRNAが発現して いた。そこで、尿酸への暴露が尿酸取り込み型輸送体URATv1の阻害薬である ベンズブロマロン、ロサルタン、イルベサルタンの存在下並びに非存在下で 
HUVECsのNO産生能に及ぼす効果を検討した。尿酸への暴露はコントロールに 比較してHUVECsでのNO産生を有意に低下させたが、ベンズブロマロン、ロサ ルタン、イルベサルタン存在下では尿酸への暴露はHUVECsでのNO産生を抑制 しなかった。次にHUVECsのeNOS発現とそのリン酸化に及ぼす尿酸暴露の効果 を検討した。尿酸への暴露はコントロールに比較して有意にリン酸化eNOSの 発現を低下させたが、total eNOS発現には影響しなかった。ベンズブロマロ ン、ロサルタン、イルベサルタン存在下では、尿酸への暴露はHUVECsのリン 酸化eNOSの発現を有意に回復させた。

\section{考 察}

HUVECsには 4 種類の尿酸取り込み型輸送体と排出型輸送体が発現し、高尿酸 血症条件下ではeNOSのリン酸化が抑制され、NO産生が阻害されることが判明 した。さらにURATv1阻害薬であるベンズブロマロン、ロサルタン、イルベサ ルタンは尿酸により誘導されるHUVECsのeNOSリン酸化障害とNO産生障害の両 方を有意に回復することができたことから、細胞内の尿酸レベルが主に URATv1によって調節され、高尿酸濃度条件下でURATv1を介して細胞内に流入 した可溶性尿酸により血管内皮機能障害が生じる可能性を示唆している。

以上の事実は尿酸輸送体URATv1の阻害薬であるベンズブロマロン、ロサル タン、イルベサルタンにより、高尿酸血症に合併する内皮機能障害が改善す る可能性が示された。

\section{結 論}

尿酸はURATv1を介してHUVECsでのeNOSのリン酸化とNO産生の障害を惹起す るが、URATv1阻害薬の前投与はこれらを回復させた。 